\title{
EFFECT OF TORREFACTION TEMPERATURE ON PROPERTIES OF PATULA PINE
}

\author{
Sergio Ramos-Carmona ${ }^{1}$, Juan F. Pérez ${ }^{1, \wedge}$, Manuel Raúl Pelaez-Samaniego ${ }^{2}$, \\ Rolando Barrera ${ }^{3}$, Manuel Garcia-Perez ${ }^{4}$
}

\begin{abstract}
The objective of this work was to study the effect of torrefaction temperature on properties of patula pine (Pinus patula) wood that could be of interest for further thermochemical processing. Torrefaction temperature was varied from 200 to $300{ }^{\circ} \mathrm{C}$ for 30 minutes using a batch spoon type reactor. Raw and torrefied materials were characterized for proximate and ultimate analyses, thermogravimetry, and pyrolysis gas chromatography/mass spectrometry (Py-GC/MS). Results showed that torrefied pine has greater higher heating value and chemical exergy due to the reduction of $\mathrm{O} / \mathrm{C}$ and $\mathrm{H} / \mathrm{C}$ ratios. Compared with raw biomass, the material torrefied at 200 and $250{ }^{\circ} \mathrm{C}$ did not present significant changes in chemical composition and thermal behavior. Conversely, material torrefied at $300{ }^{\circ} \mathrm{C}$ did show important changes in both chemical composition and thermal behavior. Py-GC/MS results suggested that the main constituents of biomass, i.e., hemicellulose, cellulose and lignin, suffer a progressive thermal degradation with increase in torrefaction temperature.
\end{abstract}

Keywords: Biomass, Chemical-energy properties, Pinus patula, pyrolysis, thermal degradation, thermochemical processes.

\section{INTRODUCTION}

Historically, wood has been a ubiquitous resource for manufacturing tools, ships, weapons, musical instruments, or for house-building, until less than a century ago. Wood has been at the same time a key fuel used worldwide. For instance, the fuel used for locomotion in the US during the 1850 s was entirely wood (Schurr and Netschert 1960) and currently there are several regions that still use abundant amounts of wood as fuel, for example, for cooking (Iiyama et al. 2014). However, since approximately the midst of the $19^{\text {th }}$ century to the beginning of the $20^{\text {th }}$ century, wood fuel has been progressively substituted by fossil fuels in several countries. Despite this reduction of wood as fuel in some regions, other structural and non-structural wood uses are unavoidable and global wood-derived products utilization has been increasing. According to FAOSTAT, the decade from 2002 to 2012 showed an impressive increase of the consumption of wood composites (e.g., by almost $200 \%$ in the case of medium density fiberboard MDF) and other wood-based products, accompanied by a slight decrease in sawn-wood utilization (by approximately 5\%) (FAOSAT 2014). This information evidences that an important component of the global wood market is constituted by wood-composites, especially MDF and particleboard.

Deforestation, growing wood demand, and environmental restrictions could affect future wood availability, as observed in tropical countries since 2009 (International Tropical Timber Organization (ITTO) 2012). Fast growing timber species and materials that today in several places are considered "residues" are alternatives to timber. In Colombia, fast growing wood species such as patula pine (Pinus patula) present enormous energy prospective due to the existence of land potentially usable

\footnotetext{
'Departamento de Ingeniería Mecánica, Facultad de Ingeniería, Universidad de Antioquia UdeA, Medellín, Colombia.

${ }^{2}$ Faculty of Chemical Sciences, Universidad de Cuenca, Cuenca, Ecuador.

${ }^{3}$ Departamento de Ingeniería Química, Facultad de Ingeniería, Universidad de Antioquia, Medellín, Colombia.

${ }^{4}$ Department of Biological Systems Engineering, Washington State University, Pullman, WA, USA.

•Corresponding author: juanpb@udea.edu.co

Received: 20.02.2016 Accepted: 05.10.2016
} 
for dedicated energy trees. The country has approximately 17 million hectares of land suitable for reforestation (Pérez and Osorio 2014). Currently, these lands are poorly used as pastureland or they are simply abandoned due to limited fertility. Thus, part of these lands have been seen as an opportunity for planting trees for both commercial use and bioenergy production (Pérez and Osorio 2014). There are evidences showing that lands not adequate for agricultural use offer potential for planting trees (Phalan 2009), without negatively impacting agricultural or pasture lands. Additionally, Colombia already possesses large plantations of this wood species (approximately $55 \%$ of the forest planted area) (Ospina et al. 2011). Small diameter pine trees and the corresponding cropping residues are expected to serve as an important raw material for producing biofuels, bioenergy, and other bio-products (Quaak et al. 1999).

For an optimum use of fast growing wood species, pretreatment operations aiming at improving some wood properties are required. The use of forest biomass for energy, chemicals, or biofuels, requires pretreatment operations to increase energy content, reduce moisture, and increase bulk density (PelaezSamaniego et al. 2013). Difficulty on hauling and processing lignocellulosic biomass in an economical way is greatly limited by these critical properties. One of the recognized strategies for improving these properties is torrefaction. Torrefaction is a mild thermochemical process conducted in oxygen-free environments at temperatures ranging from 200 to $300{ }^{\circ} \mathrm{C}$ (Bridgeman et al. 2010, Chen and Kuo 2010, Ibrahim et al. 2013, Phanphanich and Mani 2011, Xue et al. 2014). In this range of temperatures, in addition to moisture and volatiles release, degradation of hemicelluloses occurs, while cellulose is subjected to dehydration and both cellulose and lignin are subjected to partial depolymerization (da Silva Grassmann et al. 2016, Pelaez-Samaniego et al. 2013).

Several works have extensively discussed about the advantages of torrefied wood. Arias et al. (2008) studied the effect of temperature and residence time on the grindability of Eucaliptus as well as its reactivity with air, using thermogravimetry. As expected, volatiles decreased when temperature increased and the energy content (i.e., its higher heating value) and $\mathrm{C}$ content augmented. $\mathrm{O}$ content decreased when time or torrefaction temperature increased, due to the formation of $\mathrm{CO}_{2}$ and the degradation of hemicelluloses. Grindability depended on the conditions of the process: the more severe the conditions of the process, the better the degree of grindability. Repellin et al. (2010) studied the effect of torrefaction of two types of biomass (spruce and beech) on power consumption during the grinding operation. It was observed that power consumption decreased as a consequence of the thermal treatment. Similar findings have been reported by Bridgeman et al. (2010).

The process of torrefaction alters the physical properties of biomass, reducing its bulk density and its fibrous tenacious nature (da Silva Grassmann et al. 2016). This could allow increased rates of comilling and co-firing in coal fired power stations, which in turn would enable reduction of the amount of coal used and an increase in the use of renewable fuels, without the need for additional infrastructure. Phanphanich and Mani (2011) and Chen et al. (2011) investigated the pulverization behavior of two torrefied energy crops, namely: willow and Miscanthus. Results showed that the untreated fuels and materials torrefied at low temperatures had very poor grindability behavior. However, more severe torrefaction conditions caused the fuels to exhibit similar pulverization properties as coals. Medic et al. (2012) have investigated the solid, liquid, and gas products of the torrefaction of corn stover with moisture content of 3,22 , and $41 \%$. The temperature was varied from 200 to $300{ }^{\circ} \mathrm{C}$ and the residence time from 10 to $30 \mathrm{~min}$. As in other types of materials (Pelaez-Samaniego et al. 2014), the yield of solids decreased when the temperature of the process increased. This has been attributed to the degradation of hemicelluloses and probably part of cellulose (Medic et al. 2012). Pelaez-Samaniego et al. (2014) investigated the influence of torrefaction conditions on amount, composition, molecular weight, and pattern of deposition of lignin liquid intermediates (LLI). The authors mentioned that it is possible to control the conditions of the torrefaction process to increase or decrease the amount of lignin liquid intermediates on wood fibers surface, which could be of interest for pellets production and wood composites manufacture. Another option is using torrefied wood for fast pyrolysis, as reported by Yang et al. (2014). These authors conducted torrefaction of switchgrass at 230 and $270{ }^{\circ} \mathrm{C}$ prior to pyrolysis. Results showed that torrefaction promotes increase of anhydrosugars and phenols in pyrolysis bio-oil. Similar results have been obtained by Zheng et al. (2015), who studied the effect of wet and dry torrefaction on chemical structure and pyrolysis behavior of corncob. 
The mentioned works show that torrefaction, in addition to modifying critical properties of lignocellulosic biomass, can serve as a strategy to pretreat this material for further thermochemical operations. Therefore, information on the torrefaction process and the effects of softwood, such as abundant patula pine in the Colombian highlands, will help to plan the use of low quality pine (e.g., small diameter trees) and softwood cropping residues. The objective of this study is to evaluate the effect of torrefaction temperature on some properties of patula pine that are expected to impact further processing as a fuel, as a raw material for thermochemical downstream operations, or for the production of wood pellets.

\section{MATERIALS AND METHODS}

\section{Materials}

The material used for torrefaction was patula pine, obtained from a commercial plantation located nearby Medellín, Colombia. The selection of this wood species took into account the potential that it offers as an abundant lignocellulosic material in Colombian highlands. Small diameter logs were debarked before a chipping process. The wood sample was chipped using a BANDIT 95XP chipper, then located on the floor (trying to keep a uniform thickness layer of chips) and dried at room conditions during two weeks. Then, a representative amount of chips (approximately $2 \mathrm{~kg}$ ) was collected and ground, using a laboratory knife table mill, equipped with a 40 -mesh sieve. The ground material was then dried for $24 \mathrm{~h}$ at $105^{\circ} \mathrm{C}$ prior torrefaction and prior to characterization of raw material properties.

\section{Methods}

Torrefaction of the patula pine (PPat) sample was carried out in a Lindberg Blue tube furnace (spoon reactor, capacity of approximately $3 \mathrm{~g}$ of biomass per batch). The reactor is described in detail by Wang et al. (2014). Three levels of temperature were selected for torrefaction: 200,250 , and $300{ }^{\circ} \mathrm{C}$, and 30 minutes of residence time, following previous works (Pelaez-Samaniego et al. 2014, Phanphanich and Mani 2011). The samples were coded as Raw (untreated material), and PPat200, PPat250, and PPat300, for the materials torrefied at 200,250 , and $300^{\circ} \mathrm{C}$, respectively. The torrefaction process was conducted in duplicates and, due to close yields, the averages of the results are reported.

\section{Ultimate and proximate analyses}

Elemental composition (CHNS) was determined using a LECO ${ }^{\circledR}$ TruSpec CHN instrument, coupled with a LECO ${ }^{\circledR}$ 628S module (Pelaez-Samaniego et al. 2014). For CHN, approximately $0,13 \mathrm{~g}$ of oven dry material were fed in the combustion chamber of the Truspec CHN module. The S content was determined by using approximately $0,1 \mathrm{~g}$ of dried material, which was burned in the $628 \mathrm{~S}$ module. Details about the whole process can be found at (Pelaez-Samaniego et al. 2014). In all cases, the test was replicated twice to verify results. Results of ash content were used to correct the results of elemental composition of each material.

Ash content was determined following ASTM D1102-84 (reapproved 2007) for raw pine and using a correction factor (i.e., mass yield) for torrefied material. Volatiles content was determined using thermogravimetry (TGA), as suggested by previous works (García et al. 2013, Pelaez-Samaniego et al. 2014). Prior to TGA analysis, the torrefied materials were ground using the knife-mill already described. Again, particles used for the test passed through a 40 mesh sieve. For the test, a TGA equipment (TGA/ SDTA851e, Mettler Toledo) was used. The heating rate was $10^{\circ} \mathrm{C} / \mathrm{min}$ and the temperature varied from room conditions to $600{ }^{\circ} \mathrm{C}$. Approximately $7 \mathrm{mg}$ of material was employed in each case and tests were conducted in duplicate to verify results. 


\section{Heating value and chemical exergy}

The higher heating value (HHV) and chemical exergy $\left(\mathrm{e}^{\mathrm{ch}}\right)$ of the initial material and torrefied material was calculated using correlations that take into account the ultimate analysis $(\mathrm{C}, \mathrm{H}, \mathrm{N}$, $\mathrm{O}$ and S) in dry basis, following to Friedl et al. (2005) and Kotas (1995), respectively (Eqs. 1, 2, and 3). Equation 1 shows the calculus of HHV, while equations 2 and 3 show the estimation of $\mathrm{e}^{\text {ch }}$.

$$
\begin{gathered}
H H V_{b m s}(k J / k g)=3,55 C^{2}-232 C-2230 H+51,2 C H+131 N+20600 \\
e^{c h}(k J / k g)=H H V_{b m s} \lambda_{b m s}+9417 S \\
\lambda_{b m s}=\frac{1,0438+0,1882 H / C-0,2509(1+0,7256 H / C)+0,0383 N / C}{1-0,3035 O / C}
\end{gathered}
$$

Where $\lambda_{\text {bms }}$ is a dimensionless coefficient that relates the heating value and the chemical exergy of a solid fuel (Kotas 1995), and C, H, N are the elemental composition (in wt.\%).

\section{Mass and energy yield}

Mass and energy yield are important parameters used in torrefaction process as indicators of the mass degradation and energy content changes due to the thermal pretreatment (Bridgeman et al. 2010). These parameters are calculated according to Eqs. (4) and (5).

$$
\begin{gathered}
\text { Mass yield }=\frac{m_{b m s, t o r r}}{m_{b m s}} \\
\text { Energy yield }=\frac{m_{b m s, t o r r} H H V_{b m s, t o r r}}{m_{b m s} H H V_{b m s}}
\end{gathered}
$$

Where $m_{b m s}$ and $m_{b m s, t o r r}$ are the masses and $H H V_{b m s}$ and $H H V_{b m s, t o r r}$ are the higher heating values of the raw and torrefied material, respectively. The energy yield is a measure of the energy content of the torrefied biomass after the torrefaction process was carried out (Chen and Kuo 2010, Phanphanich and Mani 2011, Prins et al. 2006a).

\section{Py-GC/MS}

Characterization of the untreated and torrefied materials was also carried out using pyrolysis gas chromatography/mass spectrometry (Py-GC/MS). Py-GC/MS was performed using a GC/MS system (6890N Network GC System with a 5975B inert XL MSD, from Agilent Technologies) coupled with a CDS pyro-probe 5000 series (CDS Analytical, Inc). The tests were conducted in duplicate at $500{ }^{\circ} \mathrm{C}$ for $1 \mathrm{~min}$, using $\sim 0,5-0,8 \mathrm{mg}$ of material. Compounds that showed the highest intensity in the pyrolysis chromatograms were identified considering retention time, mass spectra, and comparison with database of the NIST/EPA/NIH Mass Spectral Library V. 2.0d (Fair Com Corp). The areas of peaks were then divided by the mass of the corresponding material for normalization of areas. 


\section{RESULTS AND DISCUSSION}

\section{Mass and energy yield}

Table 1 shows the mass and energy yields of raw and torrefied pine at different temperature conditions. As expected, the mass yield of torrefied wood decreased when torrefaction temperature increased. The mass yield for PPat200 and PPat250 was not reduced significantly compared with PPat300 where the mass loss increased drastically. The mass loss during torrefaction results from the drying process and the thermal degradation of low thermally stable wood constituents (Chen and Kuo 2010, Hill et al. 2013, Phanphanich and Mani 2011).

Table 1. Mass and energy yield of torrefied samples.

\begin{tabular}{|l|c|c|}
\hline Sample & Mass yield (\%) & Energy yield (\%) \\
\hline PPat 200 & 98,46 & 99,37 \\
\hline PPat 250 & 93,94 & 97,45 \\
\hline PPat 300 & 67,75 & 78,51 \\
\hline
\end{tabular}

The energy yield for the torrefied decreases as the temperature of the torrefaction process increases as shown in Table 1 . The mass loss increases from 1,54 to $32,25 \%$ and the heating value gain varies from 0,63 to $21,49 \%$ depending on the temperature of torrefaction. However, the HHV of torrefied woods augments (Table 2), which is associated with the modification in their elemental compositions (e.g. ultimate analysis) during torrefaction process as described in the next section.

\section{Proximate and ultimate analysis}

Table 2 shows the proximate and ultimate analyses, higher heating values, and chemical exergies of the raw and torrefied materials. A slight effect on the proximate analysis was observed in material torrefied up to $250{ }^{\circ} \mathrm{C}$, while a significant change occurs in material torrefied at $300{ }^{\circ} \mathrm{C}$. At higher torrefaction temperature, volatile matter decreases while fixed carbon and ash contents increase. Similar results were reported by Pelaez-Samaniego et al. (2014) for ponderosa pine wood species. It is also observed that the carbon content gradually increases while oxygen content decreases as the torrefaction temperature is augmented. The hydrogen and nitrogen contents remain approximately constant at all levels of torrefaction temperature; this trend is attributed to the low mass concentration of these components in wood biomass. The chemical exergy of a fuel is a measure of the maximum potential that can be obtained as useful work (Kotas 1995). Thereby, the increase of exergy (as torrefaction temperature increases) leads to higher availability of useful work using torrefied biomass as feedstock for power plants or downstream thermochemical processes.

Table 2. Proximate and ultimate analysis of raw and torrefied samples.

\begin{tabular}{|l|l|l|l|l|}
\hline Sample & Raw & PPat200 & PPat250 & PPat300 \\
\hline Proximate analysis (wt. \%, dry & basis) \\
\hline Volatile matter (VM) & 81,12 & 79,53 & 80,82 & 70,65 \\
\hline Fixed carbon ${ }^{\text {a }}(\mathrm{FC})$ & 18,62 & 20,20 & 18,90 & 28,97 \\
\hline Ash & 0,26 & 0,26 & 0,28 & 0,38 \\
\hline Ultimate analysis (w. \%, dry basis) \\
\hline $\mathrm{C}$ & 49,95 & 50,33 & 51,46 & 56,24 \\
\hline $\mathrm{H}$ & 5,94 & 5,80 & 5,70 & 5,56 \\
\hline $\mathrm{N}$ & 0,14 & 0,13 & 0,15 & 0,15 \\
\hline $\mathrm{O}^{\mathrm{a}}$ & 43,97 & 43,74 & 42,69 & 38,05 \\
\hline $\mathrm{HHV}_{\mathrm{db}}(\mathrm{MJ} / \mathrm{kg})$ & 19,84 & 19,96 & 20,40 & 22,46 \\
\hline $\mathrm{e}^{\text {ch }}(\mathrm{MJ} / \mathrm{kg})$ & 21,45 & 21,47 & 21,60 & 22,37 \\
\hline${ }^{\mathrm{a}} \mathrm{Calculated} \mathrm{by} \mathrm{difference}$ & & & & \\
\hline
\end{tabular}

Figure 1 presents a Van Krevelen diagram, showing the decomposition progression of patula pine during torrefaction. The $\mathrm{H} / \mathrm{C}$ and $\mathrm{O} / \mathrm{C}$ atomic ratios decrease as torrefaction temperature increases. This 
is due to the release of volatile matter, constituted by non-condensable $\mathrm{CO}, \mathrm{CO}_{2}$ and condensable gases such as $\mathrm{H}_{2} \mathrm{O}, \mathrm{CH}_{3} \mathrm{OH}, \mathrm{HCOOH}$ and $\mathrm{CH}_{3} \mathrm{COOH}$. Volatiles have high $\mathrm{H} / \mathrm{C}$ and $\mathrm{O} / \mathrm{C}$ ratios, implying a reduction in the $\mathrm{H} / \mathrm{C}$ and $\mathrm{O} / \mathrm{C}$ atomic ratios of the remaining solid after torrefaction process (Deng et al. 2009, Nocquet et al. 2014, Prins et al. 2006b). Materials with higher heating value and low moisture content can benefit thermochemical processes such as combustion and gasification as the reaction temperatures in those processes can be increased (Pérez et al. 2012, Torres-Fuchslocher and Varas-Concha 2015). Other authors have reported results on the changes in biomass composition (at different torrefaction conditions) that are consistent with the findings of this study (Bridgeman et al. 2010, da Silva Grassmann et al. 2016).

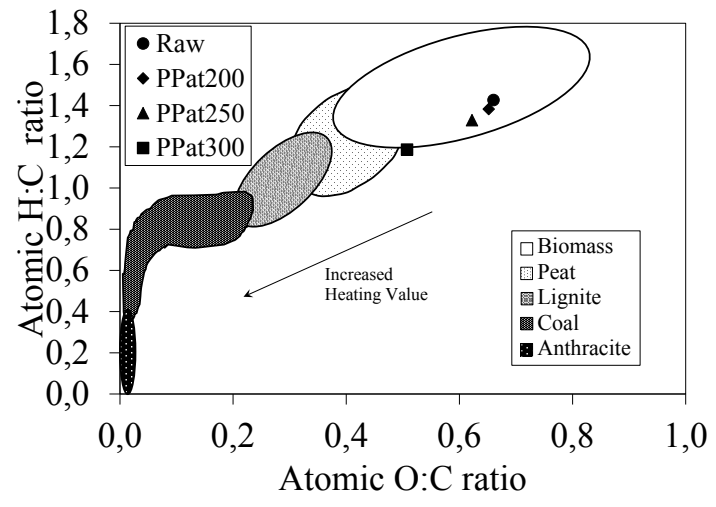

Figure 1. Van Krevelen diagram of raw and torrefied biomass.

\section{DTG results}

Figure 2 shows the TG and DTG curves of the raw and torrefied PPat to evaluate the effect of torrefaction process. The curves for torrefied material (PPat200, PPat250 and PPat300) have been multiplied for the mass yield reported in Table 1 in order to obtain the same basis (raw) for comparison purposes, following the process of Pelaez-Samaniego et al. (2014). TG curves (Figure 2a) shows that thermal stability slightly increases as torrefaction temperature increases; which is due to lower amount of volatile matter in torrefied biomass (Table 2). It is evident that material torrefied at higher temperature $\left(300{ }^{\circ} \mathrm{C}\right)$ shows better thermal stability than the other tested materials (its degradation starts at approximately $320^{\circ} \mathrm{C}$ ).

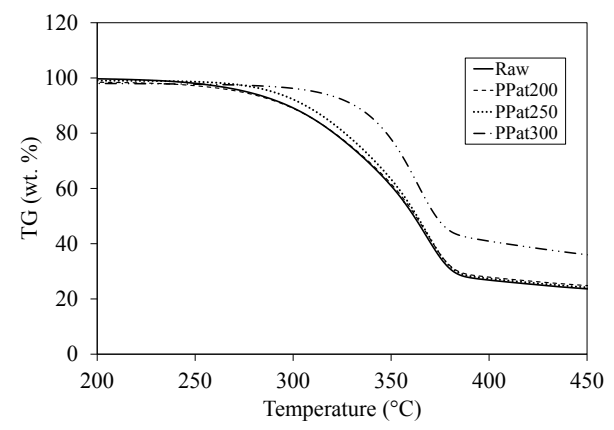

2(a) TG Curves

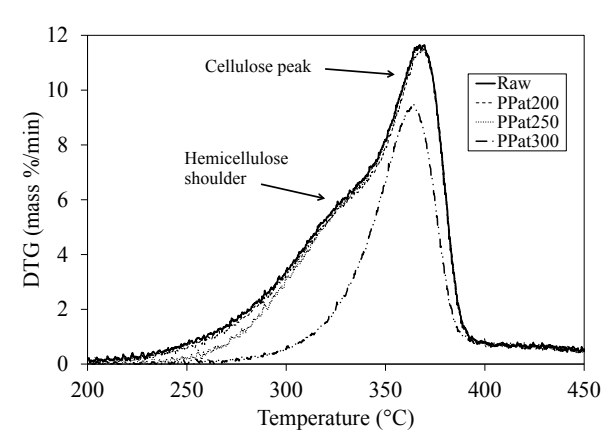

2(b) DTG Curves

Figure 2. DTG curves of raw and torrefied samples at different temperatures.

Figure $2 \mathrm{~b}$ shows the DTG curves. It can be seen that there is not significant change in biomass torrefied up to $250{ }^{\circ} \mathrm{C}$. Raw pine, PPat200 and PPat 250 exhibit a shoulder, which can be related with the presence of hemicelluloses. Absence of this shoulder in the TG curve of material torrefied at 300 
${ }^{\circ} \mathrm{C}$ could be explained in part by the partial removal of hemicelluloses during torrefaction at this temperature. The large peak at around $370{ }^{\circ} \mathrm{C}$, in all cases, can be related with the degradation of cellulose (Chen and Kuo 2010, Park et al. 2013, Pelaez-Samaniego et al. 2014). The thermal stability of the samples is consistent with the proximate and ultimate analyses in Table 2, where no major changes were observed on chemical composition of the raw material ant the samples of material torrefied at 200 and $250{ }^{\circ} \mathrm{C}$. Additionally, the peak corresponding to cellulose degradation was affected during torrefaction but its position $\left(365^{\circ} \mathrm{C}\right)$ did not change visibly. This behavior might indicate that the structural characteristics of cellulose fraction of patula pine was preserved after torrefaction process (Park et al. 2013).

\section{Py-GC/MS}

Since the results of DTG and the proximate and ultimate analyses (Table 2) suggest that the PPat200 and PPat250 samples show quite similar composition and thermal stability, we used an additional technique, Py-GC/MS to indirectly determine if, in fact, the composition of the materials has changed as a result of torrefaction. Py-GC/MS allowed the determination of the main products of the pyrolysis of the raw and torrefied materials. Figure 3 and Table 3 show the compounds resulting from the pyrolysis of each material. These compounds were classified as acids, ketones, furans, nitrogencontaining compound, sugars and phenols according to their chemical functional groups (Zhang et al. 2016).

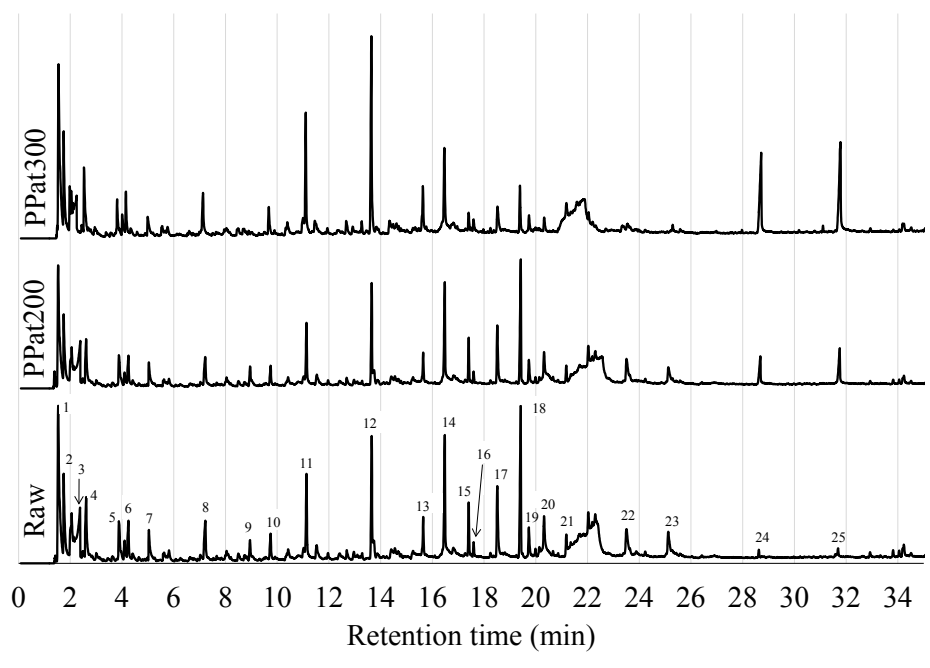

Figure 3. Chromatograms of the raw and torrefied materials. 
Table 3. Identification of the main compounds found in the Py-GC/MS chromatograms and their area/mass ratio.

\begin{tabular}{|c|c|c|c|c|c|c|}
\hline \multirow{2}{*}{ RT } & \multirow{2}{*}{$\mathrm{m} / \mathrm{z}$} & \multirow{2}{*}{ Formula } & \multirow{2}{*}{ Compound } & \multicolumn{3}{|c|}{ Area/mass } \\
\hline & & & & Raw & PPat200 & PPat300 \\
\hline \multicolumn{7}{|l|}{ Acids } \\
\hline 2,43 & 43 & $\mathrm{C}_{2} \mathrm{H}_{4} \mathrm{O}_{2}$ & Acetic acid & 155406 & 131242 & 49585 \\
\hline 28,68 & 73 & $\mathrm{C}_{16} \mathrm{H}_{32} \mathrm{O}_{2}$ & n-Hexadecanoic acid & 74136 & 74136 & 179492 \\
\hline 31,75 & 43 & $\mathrm{C}_{18} \mathrm{H}_{36} \mathrm{O}_{2}$ & Octadecanoic acid & 94661 & 94661 & 217106 \\
\hline \multicolumn{4}{|l|}{ Total } & 324202 & 300038 & 446183 \\
\hline \multicolumn{7}{|l|}{ Ketones } \\
\hline 2,66 & 43 & $\mathrm{C}_{3} \mathrm{H}_{6} \mathrm{O}_{2}$ & 2-Propanone, 1-hydroxy- & 91240 & 84480 & 93957 \\
\hline 7,33 & 98 & $\mathrm{C}_{5} \mathrm{H}_{6} \mathrm{O}_{2}$ & 2-Cyclopenten-1-one, 2-hydroxy- & 66704 & 60897 & 70513 \\
\hline 9,76 & 112 & $\mathrm{C}_{6} \mathrm{H}_{8} \mathrm{O}_{2}$ & 1,2-Cyclopentanedione, 3-methyl- & 45474 & 36005 & 47639 \\
\hline 3,89 & 43 & $\mathrm{C}_{4} \mathrm{H}_{8} \mathrm{O}_{3}$ & 1,2-Ethanediol, monoacetate & 60789 & 46165 & 46409 \\
\hline \multicolumn{4}{|l|}{ Total } & 264207 & 227547 & 258518 \\
\hline \multicolumn{7}{|l|}{ Furans } \\
\hline 5,05 & 96 & $\mathrm{C}_{5} \mathrm{H}_{4} \mathrm{O}_{2}$ & Furfural & 43340 & 44411 & 43733 \\
\hline \multicolumn{4}{|l|}{ Total } & 43340 & 44411 & 43733 \\
\hline \multicolumn{7}{|l|}{ Esters } \\
\hline 1,8 & 43 & $\mathrm{C}_{5} \mathrm{H}_{8} \mathrm{O}_{2}$ & 1-Propen-2-ol, acetate & 130609 & 102551 & 129055 \\
\hline 4,25 & 43 & $\mathrm{C}_{4} \mathrm{H}_{6} \mathrm{O}_{3}$ & Propanoic acid, 2-oxo-, methyl ester & 54736 & 42607 & 59207 \\
\hline \multicolumn{4}{|l|}{ Total } & 185346 & 145158 & 188262 \\
\hline \multicolumn{7}{|c|}{ Nitrogen-containing compounds } \\
\hline 8,95 & 114 & $\mathrm{C}_{8} \mathrm{H}_{17} \mathrm{NO}$ & Oxazolidine, 2,2-diethyl-3-methyl- & 29923 & 28720 & 0 \\
\hline \multicolumn{4}{|l|}{ Total } & 29923 & 28720 & 0 \\
\hline \multicolumn{7}{|l|}{ Sugars } \\
\hline 21,33 & 60 & $\mathrm{C}_{6} \mathrm{H}_{10} \mathrm{O}_{5}$ & Levoglucosan & 823508 & 814179 & 706676 \\
\hline \multicolumn{4}{|l|}{ Total } & 823508 & 814179 & 706676 \\
\hline \multicolumn{7}{|l|}{ Phenols } \\
\hline 11,28 & 109 & $\mathrm{C}_{7} \mathrm{H}_{8} \mathrm{O}_{2}$ & Phenol, 2-methoxy- & 104292 & 79954 & 141905 \\
\hline 13,6 & 123 & $\mathrm{C}_{8} \mathrm{H}_{10} \mathrm{O}_{2}$ & Phenol, 2-methoxy-4-methyl- & 135393 & 111258 & 252044 \\
\hline 15,65 & 137 & $\mathrm{C}_{9} \mathrm{H}_{12} \mathrm{O}_{2}$ & Phenol, 4-ethyl-2-methoxy- & 45189 & 37766 & 68296 \\
\hline 16,47 & 135 & $\mathrm{C}_{9} \mathrm{H}_{10} \mathrm{O}_{2}$ & 2-Methoxy-4-vinylphenol & 158860 & 131233 & 136737 \\
\hline 17,4 & 164 & $\mathrm{C}_{10} \mathrm{H}_{12} \mathrm{O}_{2}$ & Eugenol & 65973 & 54450 & 37899 \\
\hline 17,65 & 137 & $\mathrm{C}_{10} \mathrm{H}_{14} \mathrm{O}_{2}$ & Phenol, 2-methoxy-4-propyl- & 24619 & 18469 & 26438 \\
\hline 18,53 & 152 & $\mathrm{C}_{8} \mathrm{H}_{8} \mathrm{O}_{3}$ & Vanillin & 119131 & 98610 & 71676 \\
\hline 19,55 & 164 & $\mathrm{C}_{10} \mathrm{H}_{12} \mathrm{O}_{2}$ & $\begin{array}{l}\text { Phenol, 2-methoxy-4-(1-propenyl)-, } \\
\text { (E)- }\end{array}$ & 184856 & 156604 & 67096 \\
\hline 19,73 & 137 & $\mathrm{C}_{10} \mathrm{H}_{14} \mathrm{O}_{2}$ & Phenol, 2-methoxy-4-propyl- & 56392 & 44965 & 34565 \\
\hline 20,31 & 151 & $\mathrm{C}_{9} \mathrm{H}_{10} \mathrm{O}_{3}$ & $\begin{array}{l}\text { Ethanone, 1-(4-hydroxy-3- } \\
\text { methoxyphenyl)- }\end{array}$ & 75392 & 71623 & 35945 \\
\hline 23,53 & 137 & $\mathrm{C}_{9} \mathrm{H}_{10} \mathrm{O}_{4}$ & Vanillacetic Acid & 99430 & 87774 & 0 \\
\hline 25,12 & 178 & $\mathrm{C}_{10} \mathrm{H}_{10} \mathrm{O}_{3}$ & 4-Hydroxy-2-methoxycinnamaldehyde & 79658 & 61321 & 0 \\
\hline \multicolumn{4}{|l|}{ Total } & 1149185 & 954027 & 872601 \\
\hline \multicolumn{7}{|l|}{ Others } \\
\hline 1,57 & 44 & $\mathrm{CO}_{2}$ & Carbon Dioxide & 314536 & 248343 & 335355 \\
\hline \multicolumn{4}{|l|}{ Total } & 314536 & 248343 & 335355 \\
\hline
\end{tabular}


Acetic acid, levoglucosan and phenols are the most abundant compounds and the main decomposition products from the pyrolysis of hemicellulose, cellulose and lignin, respectively (Klinger et al. 2015, Pelaez-Samaniego et al. 2014, Yang et al. 2014, Zhang et al. 2016). Figure 4 shows the abundance of acetic acid, levoglucosan and phenols for raw and torrefied pine. It can be seen that the abundance of the three compounds decreases with torrefaction temperature. According to Zheng et al. (2015), the reduction in the acetic acid may be due to the elimination reaction of acetyl groups in hemicellulose structure. The thermal degradation of cellulose and some thermally unstable lignin compounds results in the decrease on the abundances of levoglucosan and phenols, respectively. This behavior is accentuated with the increase of the torrefaction temperature. The progressive reduction in the abundance of levoglucosan and phenols suggests that: a) cellulose is subjected to different degrees of degradation, mainly to the decomposition of the amorphous fraction, and b) the thermal degradation of lignin occurs in a wide temperature range (Pétrissans et al. 2014, Chen and Kuo 2010, Wang et al. 2014).

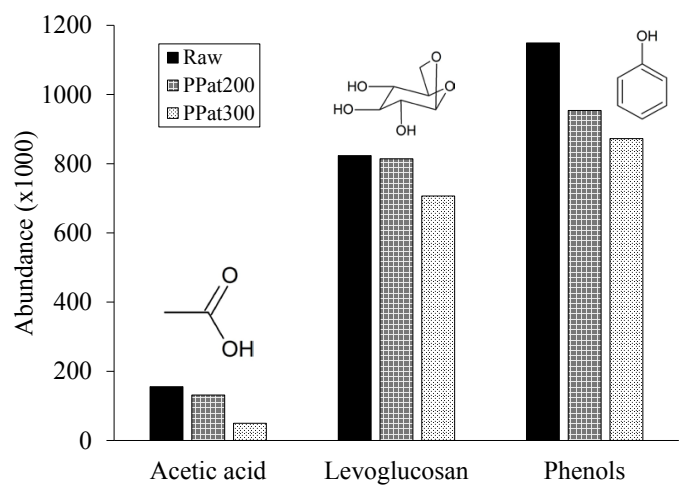

Figure 4. Effect of torrefaction on abundance of acetic acid, levoglucosan and phenols (PyGC/ MS).

The upgrading process of wood biomass via torrefaction leads to a feedstock with lower moisture content and reduced amount of light weight volatiles and hemicellulose in its structure. It is also expected that the torrefied biomass subjected to thermochemical processes such as fast pyrolysis will produce high quality products (e.g., pyrolysis bio-oil) than the corresponding untreated material. This improvement in bio-oil quality is because the bio-oil from a torrefied material is not plenty of water and light weight compounds since these were released during the torrefaction process (Yang et al. 2014, Zheng et al. 2015).

\section{CONCLUSIONS}

Torrefaction of promotes mass loss ranging from 1,5 to $32,2 \mathrm{wt}$. \%, depending on the temperature of the process. This is due to the drying process and thermal decomposition of low-molecular weight components of wood biomass. For PPat 300 , the higher heating value and chemical exergy increase up to $13,2 \%$ and $4,29 \%$ respectively, which is due to the reduction of $\mathrm{O} / \mathrm{C}$ and $\mathrm{H} / \mathrm{C}$ ratios. The found trends in molar ratios are due the $\mathrm{H}$ content reduction and/or by $\mathrm{C}$ increment with torrefaction temperature. The mass loss prevails more than the increment of heating value of torrefied biomass. Therefore, the energy content tends to diminish with torrefaction temperature. Pretreated biomasses at 200 and 250 ${ }^{\circ} \mathrm{C}$ do not present major changes in chemical composition and thermal behavior. In material torrefied at $300{ }^{\circ} \mathrm{C}$, the volatile matter decreases by $13 \%$ while fixed carbon and ash contents increase by $55,6 \%$ and $41,6 \%$ respectively. The use of torrefied wood as feedstock for thermochemical processing (e.g., fast pyrolysis and gasification) and production of pellets offers an important strategy for improving the quality of both the product. In the case of Colombia, torrefaction is a promising strategy for integration of technologies that allow a complete use of patula pine. Due to the potential of patula pine, this study could positively impact planning and management of this important wood source in the country. 


\section{ACKNOWLEDGEMENTS}

The authors acknowledge Universidad de Antioquia for the financial support of this research through the project "Estrategias de integración de la madera plantada en Colombia en conceptos de biorrefinería termoquímica: Análisis termodinámico y caracterización de bioproductos - PRG 20141016" and the Universidad de Antioquia for financial support through the project "Sostenibilidad 2015$2016 "$

\section{REFERENCES}

Pétrissans, A.; Younsi, R.M.; Chaouch, P.; Gérardin, M.P. 2014. Wood thermodegradation: experimental analysis and modeling of mass loss kinetics. Maderas-Cienc Tecnol 16:133-148.

Arias, B.; Pevida, C.; Fermoso, J.; Plaza, M.G.; Rubiera, F.; Pis, J.J. 2008. Influence of torrefaction on the grindability and reactivity of woody biomass. Fuel Process Technol 89:169-175.

Bridgeman, T.G.; Jones, J.M.; Williams, A.; Waldron, D.J. 2010. An investigation of the grindability of two torrefied energy crops. Fuel 89:3911-3918.

Chen, W.H.; Cheng, W.Y.; Lu, K.M.; Huang, Y.P. 2011. An evaluation on improvement of pulverized biomass property for solid fuel through torrefaction. Appl Energy 88:3636-3644.

Chen, W.H.; Kuo, P.C. 2010. A study on torrefaction of various biomass materials and its impact on lignocellulosic structure simulated by a thermogravimetry. Energy 35:2580-2586.

da Silva Grassmann, G.; Rogério-Andrade, C.; Dias-Júnior, A.F.; Gomes-da Silva, F.; Brito, J.O. 2016. Timber wastes torrefaction for energy use. Maderas-Cienc Tecnol 18(1):105-112.

Deng, J.; Wang, G.J.; Kuang, J.H.; Zhang, Y.L.; Luo, Y.H. 2009. Pretreatment of agricultural residues for co-gasification via torrefaction. J Anal Appl Pyrolysis 86:331-337.

FAOSAT. 2014. Global production of wood and wood derived products 2001-2012.

Friedl, A.; Padouvas, E.; Rotter, H.; Varmuza, K. 2005. Prediction of heating values of biomass fuel from elemental composition. Anal Chim Acta 544:191-198.

García, R.; Pizarro, C.; Lavín, A.G.; Bueno, J.L. 2013. Biomass proximate analysis using thermogravimetry. Bioresour Technol 139:1-4.

Hill, S.J.; Grigsby, W.J.; Hall, P.W. 2013. Chemical and cellulose crystallite changes in Pinus radiata during torrefaction. Biomass and Bioenergy 56:92-98.

Ibrahim, R.H.H.; Darvell, L.I.; Jones, J.M.; Williams, A. 2013. Physicochemical characterisation of torrefied biomass. J Anal Appl Pyrolysis 103:21-30.

Iiyama, M.; Neufeldt, H.; Dobie, P.; Njenga, M.; Ndegwa, G.; Jamnadass, R. 2014. The potential of agroforestry in the provision of sustainable woodfuel in sub-Saharan Africa. Curr Opin Environ Sustain 6:138-147.

International Tropical Timber Organization. ITTO. 2012. ITTO annual report 2012.

Klinger, J.; Bar-Ziv, E.; Shonnard, D. 2015. Unified kinetic model for torrefaction-pyrolysis. Fuel Process Technol 138:175-183. 
Kotas, T.J. 1995. The exergy method of thermal plant analysis. Krieger Publishing Company, Boston.

Medic, D.; Darr, M.; Shah, A.; Potter, B.; Zimmerman, J. 2012. Effects of torrefaction process parameters on biomass feedstock upgrading. Fuel 91:147-154.

Nocquet, T.; Dupont, C.; Commandre, J.M.; Grateau, M.; Thiery, S.; Salvador, S. 2014. Volatile species release during torrefaction of wood and its macromolecular constituents: Part 1 Experimental study. Energy 72:180-187.

Ospina, C.; Hernández, R.; Restrepo, E.; Sánchez, F.; Urrego, J.; Rondas, C.; Ramírez, C.; Riaño, N. 2011. El Pino pátula. Centro Nacional de Investigaciones de Café - CENICAFÉ. 105p. Manizales, Colombia. ISBN 978-958-8490-09-0.

Park, J.; Meng, J.; Lim, K.H.; Rojas, O.J.; Park, S. 2013. Transformation of lignocellulosic biomass during torrefaction. J Anal Appl Pyrolysis 100:199-206.

Pelaez-Samaniego, M.R.; Yadama, V.; Garcia-Perez, M.; Lowell, E.; McDonald, A.G. 2014. Effect of temperature during wood torrefaction on the formation of lignin liquid intermediates. $J$ Anal Appl Pyrolysis 109:222-233.

Pelaez-Samaniego, M.R.; Yadama, V.; Lowell, E.; Espinoza-Herrera, R. 2013. A review of wood thermal pretreatments to improve wood composite properties. Wood Sci Technol 47:1285-1319.

Pérez, J.F.; Melgar, A.; Benjumea, P.N. 2012. Effect of operating and design parameters on the gasification/combustion process of waste biomass in fixed bed downdraft reactors: An experimental study. Fuel 96:487-496.

Pérez, J.F.; Osorio, L.F. 2014. Biomasa forestal como alternativa energética: Análisis silvicultural, técnico y financiero de proyectos. Universidad de Antioquia, Medellín.

Phalan, B. 2009. The social and environmental impacts of biofuels in Asia: An overview. Appl Energy 86:S21-S29.

Phanphanich, M.; Mani, S. 2011. Impact of torrefaction on the grindability and fuel characteristics of forest biomass. Bioresour Technol 102:1246-1253.

Prins, M.J.; Ptasinski, K.J.; Janssen, F.J.J.G. 2006a. Torrefaction of wood. Part 2. Analysis of products. J Anal Appl Pyrolysis 77:35-40.

Prins, M.J.; Ptasinski, K.J.; Janssen, F.J.J.G. 2006b. Torrefaction of wood. Part 1. Weight loss kinetics. J Anal Appl Pyrolysis 77:28-34.

Quaak, P.; Knoef, H.; Stassen, H. 1999. Energy from biomass: A review of combustion and gasification technologies. World Bank Technical Paper $\mathrm{N}^{\circ} 422$.

Repellin, V.; Govin, A.; Rolland, M.; Guyonnet, R. 2010. Energy requirement for fine grinding of torrefied wood. Biomass and Bioenergy 34:923-930.

Schurr, S.H.; Netschert, B.C. 1960. Energy in the American Economy, 1850-1975: An economic study of its history ans prospects. Johns Hopkins Press.

Torres-Fuchslocher, C.; Varas-Concha, F. 2015. Design and efficiency of a small-scale woodchip furnace. Maderas-Cienc Tecnol 17:355-364. 
Wang, Z.; Pecha, B.; Westerhof, R.J.M.; Kersten, S.R. A.; Li, C.Z.; McDonald, A.G.; GarciaPerez, M. 2014. Effect of cellulose crystallinity on solid/liquid phase reactions responsible for the formation of carbonaceous residues during pyrolysis. Ind Eng Chem Res 53:2940-2955.

Xue, G.; Kwapinska, M.; Kwapinski, W.; Czajka, K.M.; Kennedy, J.; Leahy, J.J. 2014. Impact of torrefaction on properties of Miscanthus $\times$ giganteus relevant to gasification. Fuel 121:189-197.

Yang, Z.; Sarkar, M.; Kumar, A.; Tumuluru, J.S.; Huhnke, R.L. 2014. Effects of torrefaction and densification on switchgrass pyrolysis products. Bioresour Technol 174:266-273.

Zhang, S.; Dong, Q.; Zhang, L.; Xiong, Y. 2016. Effects of water washing and torrefaction on the pyrolysis behavior and kinetics of rice husk through TGA and Py-GC/MS. Bioresour Technol 199:352361.

Zheng, A.; Zhao, Z.; Chang, S.; Huang, Z.; Wang, X.; He, F.; Li, H. 2015. Comparison of the effect of wet and dry torrefaction on chemical structure and pyrolysis behavior of corncobs. Bioresour Technol 176:15-22. 